\title{
High diversity of genes encoding tetracycline resistance in the microbiota of broiler chickens in Tunisia
}

\author{
Antonietta Di Francesco ${ }^{1}$, Daniela Salvatore ${ }^{2}$, Sonja Sakhria ${ }^{3}$, Mohamed Abbassi ${ }^{3}$, Elena \\ Catelli $^{1}$, Caterina Lupini ${ }^{1}$, Ghaith Bessoussa ${ }^{4}$, Salma Ben Yahia ${ }^{3}$, and Noureddine Ben \\ Chehida $^{3}$ \\ ${ }^{1}$ University of Bologna \\ ${ }^{2}$ Affiliation not available \\ ${ }^{3}$ Institut de la Recherche Veterinaire de Tunisie \\ ${ }^{4}$ Commissariat Régional au Développement Agricole, Ben Arous, Tunisie
}

October 12, 2020

\begin{abstract}
Tetracycline resistance is still considered one of the most abundant antibiotic resistances among pathogenic and commensal microorganisms. The aim of this study was to evaluate the prevalence of tet genes encoding tetracycline resistance in broiler chickens in Tunisia, by PCR. Individual cloacal swabs from 195 broiler chickens were collected at two slaughterhouses in the governorate of Ben Arous (Grand Tunis, Tunisia). Chickens were from 7 farms and belonged to 13 lots consisting of 15 animals randomly selected. Individual whole genomic DNA was extracted and tested for 14 tet genes. All the lots examined were positive for at least 9 tet genes, with an average number of 11 tet genes per lot. Of the 195 animals tested, 194 (99\%) were positive for one or more tet genes. Tet $(\mathrm{L})$, tet $(\mathrm{M})$ and $\operatorname{tet}(\mathrm{O})$ genes were found in $98 \%$ of the samples, followed by tet(A) in $90.2 \%$, tet $(\mathrm{K})$ in $88.7 \%$ and tet $(\mathrm{Q})$ in $80 \%$. These results confirm the antimicrobial resistance impact in the Tunisian's poultry sector and suggest the urgent need to establish a robust national antimicrobial resistance monitoring plan.
\end{abstract}

\section{Hosted file}

Di Francesco et al.pdf available at https://authorea.com/users/366534/articles/486264high-diversity-of-genes-encoding-tetracycline-resistance-in-the-microbiota-of-broilerchickens-in-tunisia

\section{Hosted file}

Table 1.pdf available at https://authorea.com/users/366534/articles/486264-high-diversityof-genes-encoding-tetracycline-resistance-in-the-microbiota-of-broiler-chickens-intunisia 